\title{
БИONOTИЧECKИE HAYKИ
}

\author{
АКТУАЛЬНОСТЬ ПРИМЕНЕНИЯ МОЛЕКУЛЯРНО-БИОЛОГИЧЕСКИХ МЕТОДОВ (ПЦР) \\ ДЛЯ ВЫЯВЛЕНИЯ ДНК ВИРУСА ГЕПАТИТА В В СЕРОНЕГАТИВНОЙ ДОНОРСКОЙ КРОВИ \\ ПРИ ПАРАЛЛЕЛЬНОМ ИФА-СКРИНИНГЕ НА НВААG
}

\author{
Вальчугова Лилия Михайловна, \\ Вальчугова Юлия Сергеевна, \\ Ямпольская Татьяна Даниловна \\ Врач КЛД высшей категории ЛИиМБИ КУ «Станция переливания крови»г.Сургут; \\ студент, Сургутский государственный университет; \\ Кандидат биологических наук, дочент, Сургутский государственньй университет.
}

АННОТАЦИЯ

DOI: $10.31618 / E S U .2413-9335.2019 .5 .60 .4-6$

Серьезную опасность в трансфузиологии представляют лица с латентным гепатитом В. Исследование крови доноров только на поверхностный антиген вируса HBV - HBsAg не может обеспечить полную инфекционную безопасность крови, следствием чего может быть посттрансфузионная передача инфекции. Это объясняется тем, что вирус присутствует в организме даже при отрицательном HBsAg. B работе проанализированы данные 59110 доноров КУ"Станция переливания крови"г.Сургута, полученные в 20162018 гг.Анализировали результаты тестирования на HBsAg (методом иммуноферментного анализа) и определения ДНК вируса HBV в крови (методом полимеразной цепной реакции в «реальном времени»). Установлено, что доноры с латентным гепатитом В выявляются ежегодно, хотя и отмечена тенденция к снижению их числа. Для предотвращения распространения вируса HBV рекомендуется ввести в стандарт диагностики $\mathrm{HBV}$-инфекции совместное использование методов ИФА и ПЦР, что позволит усовершенствовать лабораторную диагностику латентной формы HBV инфекции при проведении скрининга донорской крови.

\section{ABSTRACT}

The relevance of the use of molecular biological methods (PCR) for the detection of hepatitis B virus DNA in seronegative donor blood with parallel ELISA screening for HBsAg. Persons with latent hepatitis B pose a serious danger in transfusiology. Examination of the blood of donors only for the surface antigen of the virus (hepatitis B virus, HBV) HBsAg cannot ensure complete infectious blood safety, which can result in post-transfusion infection. This is due to the fact that the virus is present in the body even with negative HBsAg. The paper analyzes the data of 59110 donors from the KU "Blood transfusion station" in Surgut, obtained in 2016-2018. Analyzed the results of testing for HBsAg (enzyme-linked immunosorbent assay) and the determination of virus DNA in the blood (by the method of polymerase chain reaction in "real time"). It was established that donors with latent hepatitis B are detected annually, although there is a tendency to a decrease in their number. To prevent the spread of the HBV virus, it is recommended that the joint use of ELISA and PCR methods be introduced into the standard for diagnosing HBV infection, which will improve the laboratory diagnosis of latent HBV infection when screening for donor blood.

Ключевые слова: лабораторная диагностика, вирусный гепатит В, иммуноферментный анализ, полимеразная цепная реакция,маркеры инфекции,донорская кровь

Keywords: laboratory diagnosis of viral hepatitis, enzyme immunoassay, polymerase chain reaction, markers of infection, donor blood.

\section{Введение}

Переливание донорской крови остается одним из ведущих вариантов передачи гемотрансмиссивных инфекций (ГТИ), наиболее опасными из которых являются вирусные гепатиты [1,c.47,3c.5]. Несмотря на применение в Службе крови высокочувствительных и специфичных методов тестирования доноров, в большинстве случаев позволяющих обеспечить безопасность гемотрансфузий, остается риск инфицирования реципиента при использовании компонентов крови от доноров, находящихся в периоде серонегативного окна. В связи с этим обеспечение инфекционной безопасности донорской крови является одним из самых актуальных и важных вопросов в лабораторной практике,в том числе ситуация связанная со своевременной и точной лабораторной выявляемостью маркеров латентной формы вируса гепатита В [3c.6,4c.33-34].
В настоящее время скрининговые лаборатории Службы крови проводят исследование образцов донорской крови на маркеры вирусного гепатита В (ВГВ) серологическими методами: иммуноферментным (ИФА) или иммунохемилюминисцентным (ИХЛА) анализом, позволяющими определять наличие в них поверхностного антигена ВГВ (HBsAg), что позволило значительно снизить риск посттрансфузионной передачи ВГВ.

$\mathrm{HBsAg}$ в большинстве случаев является наиболее значимым серологическим маркером острого и хронического ВГВ, выявление которого в крови свидетельствует с высокой степенью вероятности о присутствии в ней вируса[8c.260,10c.29-30]. Вместе с тем встречались случаи посттрансфузионного заражения ВГВ реципиентов компонентами крови при отрицательных результатах серологического 
тестирования. Например, существование «молчащей» - латентной формы гепатита В, характеризующейся низкой концентрацией вируса в крови при недетектируемом уровне $\mathrm{HBsAg}$, или наличие так называемых «ускользающих» мутантов HBsAg может привести к случаям заражения ВГВ при переливании $\mathrm{HBsAg-негативной} \mathrm{крови[1c.48,2c.12].}$ Выявление «молчащей» формы ВГВ, характеризующейся наличием низких концентраций вируса, основывается главным образом на применении высокочувствительного метода ПЦР для определения вирусной ДНК [4c.33,5c.21-22].

Цель работы: Оценка целесообразности и эффективности тестирования доноров крови путем применения комплекса лабораторных технологий

(серологических, ПЦР). Эффективность обнаружения ДНК ВГВ при отрицательном ИФА скрининге на HbsAg.

В связи с этим поставлены следующие задачи:

1.Изучить частоту выявления ПЦР-методом доноров, находящихся в периоде «серологического окна» гепатита В ( «молчащей» формой гепатита B).

2. Провести сравнительный мониторинг выявления ДНК HBV-положительных HBsAg-отрицательных доноров за три года 2016-2018гг. на базе СПК г. Сургута.

3.Доказать актуальность применения молекулярно- биологических методов(ПЦР) для выявления ДНК вируса гепатита В в серонегативной донорской крови при параллельном ИФА-скрининге на $\mathrm{HbsAg}$

4. Провести оптимизацию лабораторного процесса и оценить ее влияние на качество работы.

Материалы и методы работы

Образцы плазмы крови доноров, полученные из отдела заготовки компонентов крови СПК г.Сургута забирали в 2 пробирки: одну пробирку с разделительным гелем для получения сыворотки для серологических исследований и вторую пробирку с ЭДТА для получения плазмы для ПЦР.Скрининг донорских сывороток на серологические маркеры ВГВ проводили методом ИФА на аппарате i-Mark (компания Biorad, США).

Для выявления HBsAg методом ИФА использовали тест-системы HBsAg-ИФА-БЕСТ Набор реагентов для иммуноферментного выявления HBsантигена вируса гепатита В.Чувствительность: 0,01 ME/мЛ (нг/мл) и HBsAg-подтверждающий-ИФА-
БЕСТ Набор реагентов для иммуноферментного подтверждения присутствия HBs-антигена вируса $\begin{array}{llll}\text { гепатита } & \text { В.)Чувствительность: 0,01 } \mathrm{ME} / \mathrm{M}\end{array}$ (нг/мл).Образцы, показавшие при первичном исследовании в ИФА положительный результат на $\mathrm{HBsAg}$, отбирали для повторного исследования в тех же тест-системах и подтверждающих тестах[2c. 10,6 c. 155$]$.

Все серонегативные образцы исследовали методом ПЦР на наличие ДНК HBV. ПЦРисследования выполняли в пулах из 6 образцов на анализаторе Cobas s201 ("Roche” Швейцария) с использованием мультиплексных тест-систем CobasTagScreen в режиме реального времени[4c.33,5c.22].

Инструментальный комплекс Cobas 201 (Roche. Швейцария), включает пипетирующую рабочую станцию, аппарат для автоматического выделения нуклеиновых кислот CobasAmpliprep и анализатор CobasTaqman для автоматического проведения амплификации и детектирования нуклеиновых кислот с использованием 5 нуклеазной технологии[10c29-30]. Многоканальные оптические системы прибора позволяют регистрировать флуоресцентный сигнал от исследуемого образца в каждом цикле ПЦР[9c.202]. Для ПЦР-анализа серонегативных образцов использовали мультиплексные тест-системы CobasTaqScreen MPX Test v2, разработанные компанией Roche специально для скрининга донорской крови с соблюдением следующих правил[8c255-256]. Образцы плазмы с отрицательными результатами ИФА тестов объединяются в минипулы (6 образцов) и проверяются на наличие ДНК ВГВ. Первое молекулярно-биологическое исследование проводится в единичной постановке каждого минипула. При получении положительного результата исследование повторяют 2 раза с сохранением условий первой постановки, включая реагенты. В случае выявления хотя бы одного положительного ответа при повторном тестировании образцы анализируются индивидуально[2c.9-10,4c.33-34]

При получении позитивного результата данный образец донорской крови проверяется повторно и при воспроизведении результата признается положительным на наличие ВГВ, несмотря на имеющийся у него отрицательный результат ИФА [4c.34]. Результаты исследования представлены в таблице 1 .

Таблица 1. Результаты исследования серонегативных образцов донорской крови методом ПЦР на комплексе Cobas S 201

\begin{tabular}{|c|c|c|c|}
\hline $\begin{array}{c}\text { Годы проведения } \\
\text { исследований }\end{array}$ & $\begin{array}{c}\text { Количество образцов } \\
\text { донорской крови "се- } \\
\text { ронегативных"в ИФА } \\
\text { по НВsAg }\end{array}$ & $\begin{array}{c}\text { Количество исследований } \\
\text { образцов донорской } \\
\text { крови методом ПЦР }\end{array}$ & $\begin{array}{c}\text { Количество положительных } \\
\text { результатов в дискримина- } \\
\text { ционном тесте на ДНК НВV }\end{array}$ \\
\hline 2016 & 16580 & 16580 & 3 \\
\hline 2017 & 22208 & 22208 & 2 \\
\hline 2018 & 20322 & 20322 & 7 \\
\hline Итого & 59110 & 59110 & \\
\hline
\end{tabular}


Результаты

Детекция-идентификация вируса гепатита В:

При исследовании в течение 2016-2018гг. 59110 серонегативных образцов донорской плазмы на наличие вирусной ДНК HBV на аппаратном комплексе Cobas 201 с помощью тест-систем CobasTagScreen MPX v2 в 7 случаях было зарегистрировано нарастание флуоресцентного сигнала, свидетельствующее о наличии в образце вирусной ДНК HBV, таким образом было выявлено 7 положительных образцов донорской крови на наличие ВГВ (табл. 1). Выявляемость ВГВ за трехлетний период методом ПЦР (0,02-0,02- 0,01\%) остаётся на прежнем уровне, т.е. невысокой, так как основная часть донаций крови берется у кадровых, многократно обследованных доноров, и в тоже время выявление семи инфицированных образцов донорской крови предотвратило серьезную опасность заражения возможных реципиентов вирусом гепатита $\mathrm{B}[5 \mathrm{c} 21,7 \mathrm{c} .83]$.

\section{Выводы}

1.На фактическом материале, мы установили, что методом ПЦР из 59110 образцов донорской плазмы, показавших отрицательный результат в серологических тестах, выявлено 7 образцов (0,012\%), содержащих ДНК HBV. Подобная картина может наблюдаться как при ранней инфекции (период серонегативного окна), так и при хроническом ВГВ у лиц с подавленным иммунитетом[1с.48,6c.159]. Считается, что отрицательные результаты при детекции HBsAg у больных ВГВ могут быть вызваны низким уровнем HBsAg, образованием иммунных комплексов, а также мутациями вируса. [10] Установлено, что серологические тесты (ИФА) не могут обеспечить 100\% выявление инфицированных доноров, поскольку в их крови в период так называемого «серонегативного окна» данные маркеры инфекций отсутствуют[2c.12,4c.33].

2.Сократить серонегативное окно для гепатита В в 1,5 раза и значительно снизить риск передачи возбудителей этих инфекций через донорскую кровь и ее препараты позволяет тестирование донаций с использованием полимеразной цепной реакции (ПЦР). Таким образом, на основании полученных результатов можно заключить, что скрининг образцов донорской крови с применением ПЦРтестирования для выявления вирусной ДНК ВГВ позволит снизить риск посттрансфузионной передачи вирусного гепатита В, за счет выявления инфицированных доноров, находящихся в периоде серонегативного окна и доноров с молчащей формой инфекции.
3. Определена целесообразность применения ПЦР-методов для обследования всех категорий доноров[2c.9]. Показана необходимость обязательного применения ПЦР - тестирования образцов крови всех категорий доноров для повышения инфекционной безопасности гемокомпонентной терапии[5c.22]. Алгоритм апробации донорской крови, при котором скрининг образцов методом ПЦР проводят одновременно с исследованием их в серологических тестах, позволит повысить инфекционную безопасность гемопродукции. Показано, что оптимизация лабораторного процесса повышает качество аналитического этапа лабораторных исследований. Для повышения производительности и улучшения качества работы лаборатории необходимо регулярное проведение оптимизации лабораторного процесса с помощью применения новых лабораторных технологий, использования новых информационных программ [5c22].

\section{Литература}

1. Амплеева Н.П. Актуальные аспекты вирусного гепатита В // Н.П. Амплеева, Ю.Г. Ускова, В.Ф. Павелкина, Д.И. Базаркин, Р.З. Альмяшева // Современные проблемы науки и образования. 2015. - т. 7, № 2. - С 47-53c47-48)

2. Белякова, В.В. Генотестирование доноров на гемотрансмиссивные инфекции / В.В. Белякова, И.А. Гукасян, К.С. Момотюк, О.А. Майорова, О.Е. Кузнецов, Н.Г. Дашкова, А.А. Рагимов // Вестник службы крови России. - 2012. - №1. - С 9-12

3. ГолосоваТ.В. Гемотрансмиссивные инфекции / Т.В. Голосова, Никитин И.К. - М. : Медицинское информационное агентство, 2003.- 191 с

4. Дуданова, О.П. Диагностика хронических гепатитов / О.П. Дуданова. - Изд-во ПетрГУ, 2010. $-128 \mathrm{C}$

5. Карякин, А.В. Мониторинг безопасности донорского контингента России / А.В. Карякин, Е.Д. Скоцеляс, Л.А. Терентьева //Актуальные вопросы гематологии и трансфузиологии. - 2007. - №1. - С $21-22$

6. Тетова, В.Б. Ведение вирусного гепатита В у гематологических пациентов / В.Б. Тетова, Н.М. Беляева, М. Ю. Кесаева М.Ю // Практическая медицина. - 2012. - №5. - С 155-159

7. Allain, J.P. Occult hepatitis B virus infection: implication in transfusion / J.P.Allain. // Vox Sang, 2004. - .№ 2, P 83-91

8. Busch, M.P A new strategy for estimating risk of transfusion-transmitted viral infections based on rates of detection of resently infected donors / M.P. Busch, S.A. Glynn, S.L. Strainer // Transfusion, 2004. - №2, P 254-264

9. Gutierrez, C.Molecular and serological evaluation of surface antigen negative hepatitis B virus infection in blood from Venezuela / C.Gutierrez, M. Devesa, C.L. Loureiro // J.Med.Virol, 2004. - №2. - P 200-207

10. Herman, S. Performance characteristics of a new multiplex NAT screening test for $\mathrm{HBV}, \mathrm{HCV}$ and HIV. The Cobas TagScreen MRX Test on the COBAS S 201 system / S .Herman, Y. Ohhashi, E. Kyger // Vox Sang, 2007. - Vol.91. - P 29-48 
Гасанова Ульвия Олег.

Кандидат фил.наук, г. Баку.

Университет Одлар Юрду.

CELLULOSE DECOMPOSING FEATURES BACTERIAS ARE RELATED TO CARBON, TEMPERATURE AND HUMIDITY.

Hasanova Ulviyya Oleg

PhD candidate

Odlar Yurd University, Baku

\begin{abstract}
АННОТАЦИЯ.
Данная статья посвящена изучению численности ЦРБ при воздействии сырой нефтью. Был проведен модельный эксперимент в течении 60 дней. Численность целлюлолитических бактерий определяли путем высева на агаризованную среду Гетчинсона с натриевой солью карбоксиметилцеллюлозы. Было выявлено, что через 60 дней после загрязнения серо-бурой почвы сырой нефтью имеет место снижение содержания ЦРБ в почве, при этом обнаруживается прямая зависимость между степенью загрязнения и снижением численности ЦРБ в почве. Результаты воздействия нефти на ЦРБ дают основание использовать эту группу микроорганизмов в качестве индикаторной при воздействии нефтяных углеводородов на почву. В этой связи в качестве индикаторной группы при оценке эффективности способов биоремедиации предлагается использовать целлюлозоразлагающие микроорганизмы. Эта группа высокочувствительна к ксенобиотикам и чутко реагирует на улучшение условий обитания при биоремедиации. Для серо-бурых почв основным фактором, оказывающим воздействие на численность и активность ЦРМ является показатель влажности. Этим можно объяснить тот факт, что в условиях Апшеронского полуострова органические остатки быстро минерализуются и накопление гумусовых веществ крайне замедленны, негативно воздействуя на потенциальное плодородие этих почв.
\end{abstract}

\title{
ABSTRACT.
}

This article is dedicated to the study the CDB strenght when exposed to crude oil. The model experiment was conducted withing 60 days. The strength of cellulolytic bacteria was determined by plating on Getchinson's agar medium with carboxymethylcellulose sodium salt. It was found that 60 days after the contamination of gray-brown soil with crude oil there is a decrease in the CDB content in the soil, and a direct correlation is found between the degree of pollution and the decrease in the CDB number in the soil. The results of the impact of oil on CDB give grounds to use this group of microorganisms as an indicator when exposed to petroleum hydrocarbons on the soil. In this regard, as an indicator group in evaluating the effectiveness of bioremediation methods, it is proposed to use cellulose-decomposing microorganisms.

This group is highly sensitive to xenobiotics and sensitively responds to improved living conditions during bioremediation. For gray-drilled soils, the main factor affecting the number and activity of CDM is the moisture index. This may explain the fact that in the conditions of the Absheron Peninsula, organic residues are rapidly mineralized and the accumulation of humic substances is extremely slow, negatively affecting the potential fertility of these soils.

Условия внешней среды имеют большое значение для жизни микроорганизмов. Температура и влажность, наличие кислорода, загрязненность и другие факторы среды влияют на рост микроорганизмов и распространение их в природе.

Цель нашего эксперимента состояла в определении численности ЦРБ в разных условиях, при условии введения сырой нефти в почву.

Для определения воздействия сырой нефти на численность ЦРБ проводили модельный эксперимент. В почву, отобранную с территории маслиновой рощи, в лабораторных условиях вносили сы- рую нефть месторождения Бинагади. Степень загрязнения от 0,1 до 5\%. Почву помещали в термостат при температуре $26^{\circ} \mathrm{C}$. Продолжительность модельного эксперимента 60 дней. В процессе культивирования в почве поддерживали влажность на уровне 50-60\% от полной полевой влажности. Численность ЦРМ в почве определяли в начале и по истечении 60 дней. Численность целлюлолитических бактерий определяли путем высева на агаризованную среду Гетчинсона с натриевой солью карбоксиметилцеллюлозы (Na-КМЦ). Результаты представлены в табл.1. 